\title{
DRYING BEHAVIOUR OF CASSAVA (Manihot esculenta) CHIPS
}

\author{
Saheeda Mujaffar ${ }^{1 *}$ and Amanda Lalla ${ }^{2}$ \\ ${ }^{1,2}$ Faculty of Engineering, The University of the West Indies, Trinidad \\ ${ }^{1}$ Email: saheeda.mujaffar@ sta.uwi.edu*(Corresponding author) \\ 2Email: alakshmil@gmail.com
}

\begin{abstract}
Interest in exporting dried chips form Trinidad and Tobago for use in the production of extruded snacks led to the investigation of the drying of the popular local variety MMEX 59. Drying of cassava (Manihot esculenta Crantz) chips of two sizes ( $3 \mathrm{x}$ $2 \times 1 \mathrm{~cm}$ and $0.8 \times 0.6 \times 0.4 \mathrm{~cm})$ was carried out in a natural convection $(<0.5 \mathrm{~m} / \mathrm{s})$ cabinet type dryer at $60^{\circ} \mathrm{C}$. Samples were dried until constant weight was achieved. Analyses included determination of moisture content (\% wet basis), $\mathrm{pH}$, crude protein (\%), crude fibre, fat $(\%)$, ash $(\%)$ and $\mathrm{HCN}(\mathrm{mg} / \mathrm{kg})$. Drying data was used to generate rate and Moisture Ratio (MR) curves and thin layer models applied to the MR data. The moisture content of chips was reduced from $1.57 \mathrm{~g} \mathrm{H}_{2} \mathrm{O} / \mathrm{g} \mathrm{DM}(61.06 \% \mathrm{wb})$ to $0.02 \mathrm{~g} \mathrm{H}_{2} \mathrm{O} / \mathrm{g} \mathrm{DM}$ $(2.12 \% \mathrm{wb})$ and the rate of decline in moisture was significantly affected by piece size. Equilibrium moisture values were attained after $18 \mathrm{~h}$ for the larger chips and $14 \mathrm{~h}$ for the smaller chips. Drying to a safe moisture content of $13 \%(\mathrm{wb})$ was achieved after $7 \mathrm{~h}$ for the larger chips and $3 \mathrm{~h}$ for the smaller chips. Drying of all samples occurred in the falling rate period only and drying was described through the drying rate constant $\left(\mathrm{k}_{1}\right)$. The cyanide content of the dried chips was well below the maximum acceptable limit. While size did not affect overall appearance and quality of the dried product, the smaller chip size $(0.8 \times 0.6 \times 0.4 \mathrm{~cm})$ would be recommended for cassava export based on the rapid drying rate. Curve fitting of the moisture ratio (MR) data resulted in the application of mathematical models which successfully predicted the extent of drying with respect to drying time as well as the moisture content of the cassava chips. It is hoped that this can form the basis of further studies which will look at the prediction of moisture content changes in dried cassava chips at a range of drying temperatures and cassava chip sizes.
\end{abstract}

Keywords: Cassava chips, Drying kinetics, Thin layer models

https://doi.org/10.47412/HJAK5456

\section{Introduction}

Dried cassava (Manihot esculenta Crantz) pieces are the most common form in which dried cassava roots are marketed from exporting countries such as Nigeria, Ghana, the United Republic of Tanzania, the Philippines and some parts of Asia for use in food applications, livestock feeds and ethanol production. The dried pieces, often referred to as "chips", are irregular slices or pieces of roots not normally longer than $5 \mathrm{~cm}$ in length for ease of storage in silos. Due to the importance of this commodity, standards and specifications have been developed for dried cassava chips with respect to quality and compositional requirements and the maximum moisture content is given as $13-14 \%$ wet basis [1,2].

In the Caribbean region cassava is a staple in local diets. The freshly harvested grated cassava is used in sweet dessert items and snacks and boiled tubers are normally eaten as the main starch in a meal or fried as chips [3]. More recently, cassava roots are dried and blended into flours, which are used in bakery products 
such as breads and cakes. The tubers of this variety are cylindrical with a light brown peel and cream flesh. The variety is considered suitable for primary processing into flour, which can then be used in baked goods and extruded snacks [4]. No published works exist on the drying behaviour of the local varieties of cassava.

The processing steps to produce dried cassava chips are simple and consist of washing, peeling and slicing or chipping the roots, followed by sun drying in thin layers either on concrete floors or in trays. The disadvantages of sun drying include inconsistent drying due to weather dependence, long drying times (26 days) and exposure of material to insects and pests. An additional complication of sun drying is the lower drying efficiency due to the reflection of sunlight from the white chips [5]. Oven drying of cassava roots has therefore been explored as an alternative to sun drying. To better understand the drying process, research works have focussed on the drying behaviour of cassava slices, cubes and irregular pieces in various ovens and dryers using hot air, with and without drying pre-treatments. Most of the drying works have been conducted in Nigeria, due to the socio-economic importance of the commodity in that country.

Studies on cassava drying have arisen usually out of a specific need by the cassava processing industry to produce dried chips of a specific size. Published works on the drying of cassava pieces have reported on a range of sizes and geometry, including cubes $(2.5 \mathrm{~mm}, 5 \mathrm{~mm}, 3 \mathrm{~cm})$, rectangles $(5 \times 2 \times 0.4 \mathrm{~cm})$ or slices of varying thickness $(3-7 \mathrm{~mm})$, drying conditions $\left(35-120^{\circ} \mathrm{C}, 0.5\right.$ to $\left.2.0 \mathrm{~m} / \mathrm{s}\right)$ as well as drying equipment [511]. Several of the studies reported on different aspects of the drying behaviour of the roots, such as moisture, drying rate and moisture ratio curves [7, 9-13] the determination of drying rate constants [13] and calculation of the diffusion coefficient $[9,10,13]$. Modelling or curve fitting was carried out by several researchers using one to seven thin layer models [7, 9-14].

Interest in exporting dried chips form Trinidad and Tobago for use in the production of extruded snacks led to the investigation of the drying of the popular local variety MMEX 59. The objective of this work was to therefore investigate the thin layer drying of MMEX 59 cassava chips dried at $60^{\circ} \mathrm{C}$ in a mechanical oven. The specific objectives of the study included the presentation of drying (moisture) and drying rate curves, determination of drying rate constants and modelling of the data using well-known thin layer models, with a view to characterising and predicting drying behaviour.

\section{Materials and Methods}

\subsection{Raw material preparation}

Fresh cassava (Manihot esculenta) roots (var. MMEX 59) were purchased from local farmers and kept at room temperature (approximately $30^{\circ} \mathrm{C}$ ) until use. The roots were washed and peeled manually and cut into logs $0.10-0.15 \mathrm{~m}$ in length. The cassava logs were first cut in an in-house mechanical chipper which consisted of rotating blades powered by a motor. Sample piece size was then further reduced using a benchtop bowl chopper (Hobart, Ohio, USA). The final piece size achieved depended on the time in the bowl cutter. Cassava chips were then packaged in plastic bags, heat sealed and placed in a chiller at approximately $4^{\circ} \mathrm{C}$ until required.

\subsection{Drying equipment and procedure}

Drying was carried out in a Unitemp drying cabinet (LTE Scientific Ltd., Greenfield, Oldham) with internal dimensions $1.11 \times 0.79 \times 0.61 \mathrm{~m}$. The air flow was determined to be $<0.5 \mathrm{~m} / \mathrm{s}$. The initial weights $(\mathrm{g})$ of the empty lined trays were measured using an Explorer Pro Balance, Model EP2102C (Ohaus Corporation, NJ, USA). Wire mesh trays $(0.25 \times 0.16 \times 0.04 \mathrm{~cm})$ lined with synthetic mesh material were used to hold cassava samples for drying. The trays with the samples were removed at regular intervals, quickly weighed, then returned to the dryer, until there was no apparent change in weight. At this point, drying was considered completed. 


\subsection{Drying variables}

Based on preliminary work, the best average piece sizes for drying were determined to be $3 \times 2 \times 1 \mathrm{~cm}$ and $0.8 \times 0.6 \times 0.4 \mathrm{~cm}$ as there were also comparable to those used in prior studies [7]. Larger pieces took a longer time to dry and small pieces tended to agglomerate during drying, reducing drying rates and resulting in non-uniform drying. Drying at $60^{\circ} \mathrm{C}$ was found to be optimum in terms of drying time and final quality of the chips [8]. The experimental plan is outlined in Table 1.

Table 1: Experiment plan for drying of cassava chips.

\begin{tabular}{|l|c|c|}
\hline Parameters & Size 1 $(\mathrm{S} 1)$ & Size 2 $(\mathrm{S} 2)$ \\
\hline Average particle size $(\mathrm{cm})$ & $3.0 \times 2.0 \times 1.0$ & $0.8 \times 0.6 \times 0.4$ \\
\hline Average Piece volume $\left(\mathrm{cm}^{3}\right)$ & 6.0 & 0.20 \\
\hline Average number of particles per 100g & 33 & 656 \\
\hline Tray loading capacity $\left(\mathrm{kg} / \mathrm{m}^{2}\right)$ & 2.82 & 2.84 \\
\hline Drying temperature $\left({ }^{\circ} \mathrm{C}\right)$ & 60 & 60 \\
\hline
\end{tabular}

\subsection{Quality assessment}

The moisture content of the fresh and dried MMEX 59 samples was determined using a Halogen Moisture Analyzer HB43-S (Mettler Toledo-AG, Zurich, Switzerland) set at $100^{\circ} \mathrm{C}$. Sample $\mathrm{pH}$ was measured using an Orion Star 210 benchtop pH meter (ThermoFisher Scientific, Mass., USA) with 10g of cassava blended in $30 \mathrm{ml}$ of water. Crude protein content (\%), fat content (\%), ash content (\%) and HCN content (mg/kg) were determined using AOAC Official Methods 954.01, 2006.3, 923.03 and 973.19, respectively [15]. Crude fibre (\%) was determined using the AOAC Official Method 978.10 [16].

\subsection{Drying data analysis}

Weight changes recorded during drying was used together with the dry matter values obtained from the final moisture content measurements to back-calculate the moisture changes in cassava chips during the drying process. Drying rate curves were constructed and moisture ratio (MR) calculated based on the analytical solution of Fick's Law for an infinite slab assuming uniform initial moisture distribution and negligible external resistances (Eq. 1). The drying rate constant (k) was determined from plots of ln MR versus time $(\mathrm{t})$.

$$
\begin{gathered}
M R=\frac{M-M_{e}}{M_{0}-M_{e}}=A \exp ^{-k t} \\
k=\frac{\pi^{2} D_{e f f}}{4 L^{2}}
\end{gathered}
$$

Nineteen (19) empirical and semi-empirical thin layer models given in Table 2 were applied to the MR data and the performance (fit) of the models assessed through the use of the coefficient of determination $\left(\mathrm{R}^{2}\right)$, root mean square error (RMSE) and the chi-square statistic $\left(\chi^{2}\right)$ [17-18]. Model fit was done using Curve Expert Professional software (Version 2.3.0) [19]. 
Table 2: Thin layer drying models.

\begin{tabular}{|c|c|}
\hline Model name & Equation \\
\hline Newton & $\mathrm{MR}=\exp (-\mathrm{Kt})$ \\
\hline Page & $\mathrm{MR}=\exp \left(-\mathrm{Kt}^{\mathrm{n}}\right)$ \\
\hline Modified Page & $\mathrm{MR}=\exp (-\mathrm{Kt})^{\mathrm{n}}$ \\
\hline Henderson and Pabis & $\mathrm{MR}=\mathrm{a} \exp (-\mathrm{Kt})$ \\
\hline Modified Henderson and Pabis & $\mathrm{MR}=\mathrm{a} \exp (-\mathrm{Kt} t)+\mathrm{b} \exp (-\mathrm{gt})+\mathrm{c} \exp (-\mathrm{ht})$ \\
\hline Logarithmic & $\mathrm{MR}=\mathrm{a} \exp (-\mathrm{Kt})+\mathrm{c}$ \\
\hline Two-Term & $M R=a \exp \left(-K_{0} t\right)+b \exp \left(-K_{1} t\right)$ \\
\hline Two-Term Exponential & $M R=a \exp (-K t)+(1-a) \exp (-K a t)$ \\
\hline Wang \& Singh & $\mathrm{MR}=1+\mathrm{at}+\mathrm{bt}^{2}$ \\
\hline Verma & $M R=a \exp (-k t)+(1-a) \exp (-g t)$ \\
\hline Hii & $\mathrm{MR}=\mathrm{a} \exp \left(-\mathrm{Kt}^{\mathrm{n}}\right)+\mathrm{c} \exp \left(-\mathrm{gt}^{\mathrm{n}}\right)$ \\
\hline Midilli & $M R=a \exp \left(-K t^{n}\right)+b t$ \\
\hline Weibull distribution & $\mathrm{MR}=\mathrm{a}-\mathrm{b} \exp \left(-\mathrm{Kt}^{\mathrm{n}}\right)$ \\
\hline Diffusion approach & $M R=a \exp (-K t)+(1-a) \exp (-K b t)$ \\
\hline Aghbashlo et al. & $\mathrm{MR}=-\mathrm{K}_{1} \mathrm{t} /\left(1+\mathrm{K}_{2} \mathrm{t}\right)$ \\
\hline Logistic & $\mathrm{MR}=\mathrm{a}_{0} /((1+\mathrm{a} \exp (\mathrm{Kt}))$ \\
\hline Jena and Das & $M R=a \exp \left(-K t+b t^{1 / 2}\right)+c$ \\
\hline Demir et al. & $\mathrm{MR}=\mathrm{a} \exp \left(-\mathrm{Kt}^{\mathrm{n}}\right)+\mathrm{c}$ \\
\hline Alibas & $\mathrm{MR}=\mathrm{a} \exp \left(-\mathrm{Kt}^{\mathrm{n}}+\mathrm{b} \mathrm{t}\right)+\mathrm{g}$ \\
\hline
\end{tabular}

\section{Results and Discussion}

Weight reduction of MMEX 59 cassava chips averaged 60\% (calculated over the original weight) for both chip sizes. As expected, weight reduction occurred at a faster rate for the smaller chips. The yield of dried chips averaged $40 \%$ (w/w). Both sizes of chips dried to a light off-white colour. Dried cassava chips should be typical of the colour of the variety used and are usually white, cream or yellow $[1,2]$.

The initial moisture content of MMEX 59 cassava chips averaged $1.57 \mathrm{~g} \mathrm{H}_{2} \mathrm{O} / \mathrm{g} \mathrm{DM}(61.06 \% \mathrm{wb})$ and the moisture content of dried chips were averaged $0.02 \mathrm{~g} \mathrm{H}_{2} \mathrm{O} / \mathrm{g} \mathrm{DM}(2.12 \% \mathrm{wb})$ for both the larger and smaller chips. The changes in the moisture values of chips during drying are given in Fig. 1. This reduces the drying time over traditional sun-drying, which can average $31 \mathrm{~h}$ of continuous drying [7].

The decline in moisture content was greater in smaller pieces (S2). After $4 \mathrm{~h}$ of drying, moisture content values averaged 0.51 and $0.07 \mathrm{~g} \mathrm{H}_{2} \mathrm{O} / \mathrm{g} \mathrm{DM}$ (33.75 and 6.54\% (wb)), respectively. Equilibrium moisture values were attained after $18 \mathrm{~h}$ for the larger chips and $14 \mathrm{~h}$ for the smaller chips, however drying of smaller chips was $98 \%$ complete after $7 \mathrm{~h}$ of drying. To attain a final moisture value of $13 \% \mathrm{wb}\left(0.15 \mathrm{~g} \mathrm{H}_{2} \mathrm{O} / \mathrm{g}\right.$ 
$\mathrm{DM}$ ), chips could be dried for approximately $7 \mathrm{~h}$ for the larger chips (S1) and 3h for the smaller chips (S2).

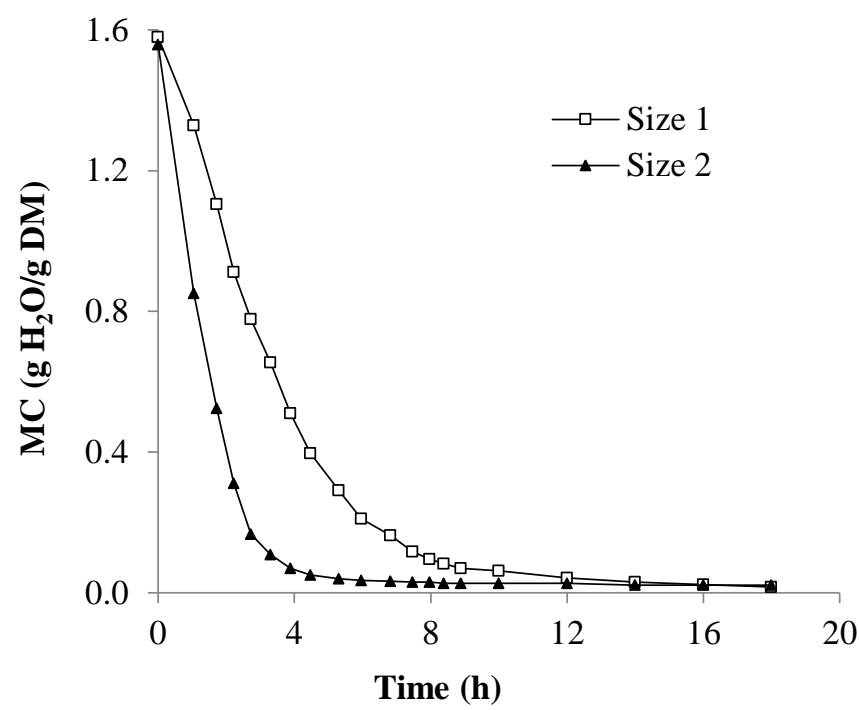

Figure 1: Moisture changes in cassava chips during drying.

Size $1(3.0 \times 2.0 \times 1.0 \mathrm{~cm})$ Size $2(0.8 \times 0.6 \times 0.4 \mathrm{~cm})$

Plots of drying rate versus average moisture content for the cassava chips are given in Fig. 2. Compared with the larger chip size (S1), initial drying rates for the first hour of drying were higher for the smaller chips (S2). Rates averaged $0.70 \mathrm{~g} \mathrm{H}_{2} \mathrm{O} / \mathrm{g}$ DM.h for the smaller chips and $0.25 \mathrm{~g} \mathrm{H}_{2} \mathrm{O} / \mathrm{g}$ DM.h. for the larger chips. Beyond $2 \mathrm{~h}$ of drying, drying rates declined rapidly while drying rates for the larger chips (S1) declined more gradually. As reported by other researchers [10,12,13], drying of chips occurred in the falling rate period. For the larger chips (S1) there was an initial warm up period between moisture values of 1.10 to $1.60 \mathrm{~g} \mathrm{H}_{2} \mathrm{O} / \mathrm{g} \mathrm{DM}$, after which rates decreased steadily. A decline in drying rate indicates that moisture diffusion is the mechanism of moisture loss.

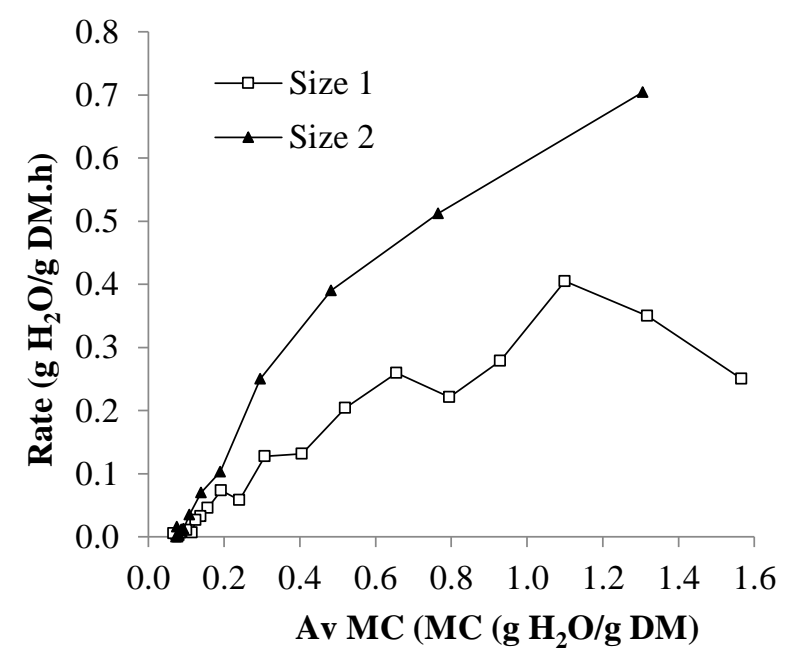

Figure 2. Changes in the drying rates of cassava chips as a function of average moisture content.

Size $1(3.0 \times 2.0 \times 1.0 \mathrm{~cm})$ Size $2(0.8 \times 0.6 \times 0.4 \mathrm{~cm})$ 
Drying rate constants $(k)$ determined from plots of $\ln$ MR versus time $(t)$ averaged $0.42911 / \mathrm{h}\left(\mathrm{R}^{2}=0.9966\right)$ and $1.02871 / \mathrm{h}\left(\mathrm{R}^{2}=0.9945\right)$ for the larger (S1) and smaller (S2) chips, respectively.

With regard to curve fitting, four (4) models could be used with success to describe the data for the larger chips (S1), namely, Hii, Two-term, Two-term exponential and Verma. The Page model was found to best fit the MR data for the smaller chips (S2), as also reported by some researchers [7,11]. The agreement in values between the predicted versus the experimental MR values using the Hii and Page models, respectively, is shown in Fig 3. Model constants, RMSE and the chi-square statistic $\left(\chi^{2}\right)$ are given in Table 3. Other models recommended by researchers for cassava chips include the modified Page model and the logarithmic model $[11,13]$. It should be noted that no previous works reported on the testing of as large a range of models as this study. The results also highlight that the drying behaviour is dependent on the chip size and drying conditions employed.

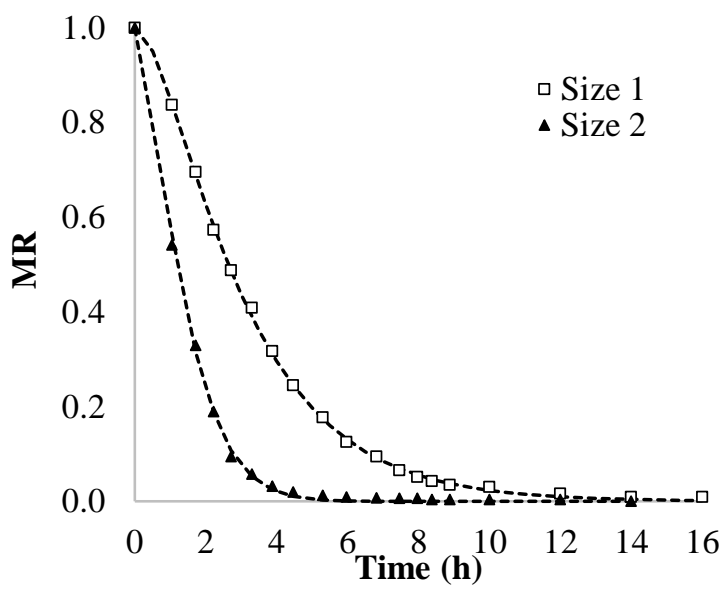

Figure 3: Experimental versus predicted (----) MR values for cassava chips, using the Hii and Page models. Size $1(3.0$ x 2.0 x $1.0 \mathrm{~cm})$ Size $2(0.8$ x 0.6 x $0.4 \mathrm{~cm})$

Table 3: Thin layer models constants for dried cassava chips, based on the Hii model.

\begin{tabular}{|c|c|c|c|c|c|c|c|c|c|}
\hline & & \multicolumn{5}{|c|}{ Model constants } & \multirow{2}{*}{$\mathrm{R}^{2}$} & \multirow{2}{*}{ RMSE } & \multirow{2}{*}{$\chi^{2}$} \\
\hline Sample & Model & $\mathrm{K}$ & $\mathrm{a}$ & $\mathrm{n}$ & $\mathrm{c}$ & $\mathrm{g}$ & & & \\
\hline S1 & Hii & 0.6550 & 8.0190 & 0.9110 & $\begin{array}{l}-7.018 \\
\end{array}$ & 0.7500 & 0.9998 & 0.006271 & 0.000053 \\
\hline S2 & Page & 0.5324 & - & 1.4339 & - & - & 0.9997 & 0.008439 & 0.000080 \\
\hline
\end{tabular}

Based on the above, the equations representing the drying process and that can be used to predict the MR values during the drying process are therefore as given in Eqns. 3-4:

$$
\begin{aligned}
& \text { Size 1: } M R=\left(8.0190 \times \exp ^{-0.6550 \times t^{0.9110}}\right)+\left(-7.018 \times \exp ^{-0.7500 \times t^{0.9110}}\right) \\
& \text { Size 2: } M R=\exp ^{-05324 x^{1.4339}}
\end{aligned}
$$

The moisture ratio (MR) values (also called the unaccomplished drying ratio) give an indication of the \% of drying that has been completed. For example, a MR value of 1.00 at the start of drying indicates that $100 \%$ of the drying process in incomplete, which is the same as $0 \%$ complete. Similarly, a MR value of 0.00 at the end of the drying process indicates that $0 \%$ of the drying process in incomplete, or, drying is $100 \%$ complete. 
Using the proposed models together with the experimentally determined initial and equilibrium moisture values, a drying operator can predict the moisture ratio as well as the actual moisture content of cassava chips at any time (t) during the drying process at $60^{\circ} \mathrm{C}(<0.5 \mathrm{~m} / \mathrm{s})$. This approach gave results in good agreement with the experimental moisture content data (Fig. 4). There was some difficulty in predicting the initial decline in moisture values for the larger chips (Fig. 4A) due to the initial warm-up period. This information could be used to set up a simple database which would enable an operator to predict the moisture content of cassava chips at any time (t) during the drying process. Future work can be carried out to establish the model constants (K, a, n, c, g) at drying at different temperatures [20], as well as for various chip sizes, depending on the equipment used in the size reduction process.

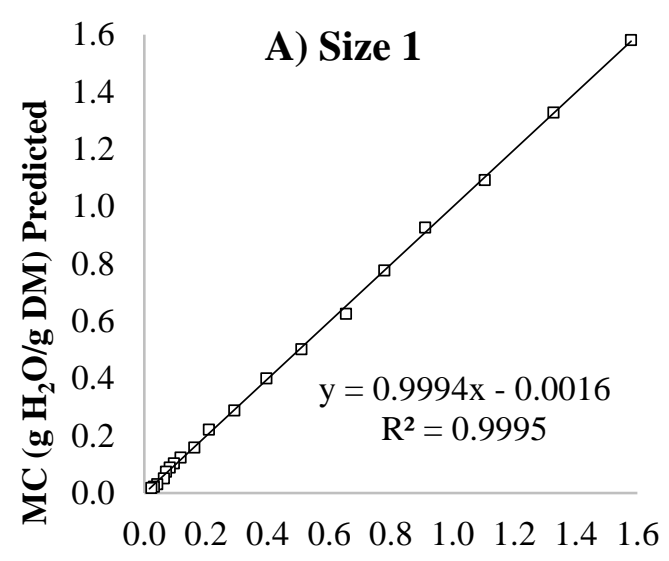

$\mathrm{MC}\left(\mathrm{g} \mathrm{H}_{2} \mathrm{O} / \mathrm{g} \mathrm{DM}\right)$ Experimental

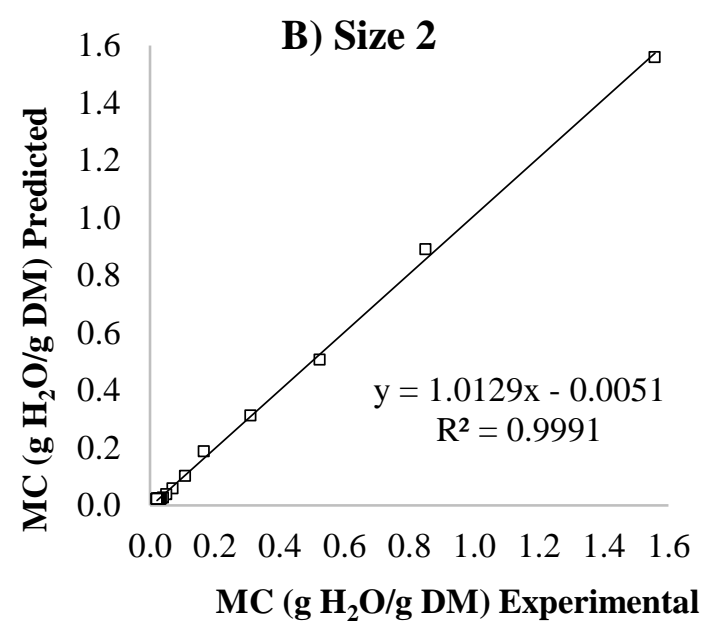

Figure 4. Experimental versus predicted moisture content values for cassava chips, back calculated using the Hii and Page models, respectively. A) Size $1-3.0$ x 2.0 x $1.0 \mathrm{~cm} \mathrm{~B}$ ) Size $2-0.8$ x 0.6 x $0.4 \mathrm{~cm}$

The smaller cassava chips (S2: $0.8 \times 0.6 \times 0.4 \mathrm{~cm}$ ) dried at a much faster rate with no visible negative effects, therefore this size was selected for further analytical work. The results of the quality analyses for dried cassava chips are given in Table 4. Values obtain fall within the specifications given in national standards as well as by previous researchers [9]. Cassava contains cyanogenic glycosides which are broken down as a result of enzymatic hydrolysis to release hydrogen cyanide which is toxic to both animals and humans [21]. Sweet cassava roots contain less than $50 \mathrm{mg} / \mathrm{kg}$ hydrogen cyanide on fresh weight basis, whereas bitter cassava varieties may contain up to $400 \mathrm{mg} / \mathrm{kg}$ [21]. Sweet cassava roots can generally be made safe to eat by peeling and thorough cooking while bitter cassava roots normally require more extensive processing. Adequately processed cassava flour and cassava-based products have very low cyanide contents and are considered safe to use [22-23]. The specification for the maximum hydrocyanic acid (HCN) content is $10 \mathrm{mg} / \mathrm{kg}$ dry weight $[1,2]$.

Table 4: Quality assessment of fresh and dried cassava chips.

\begin{tabular}{|l|c|c|}
\hline Analysis & Fresh Cassava & Dried Cassava \\
\hline Ash $(\mathrm{g} / 100 \mathrm{~g})$ & 0.032 & 0.029 \\
\hline Protein $(\mathrm{g} / 100 \mathrm{~g}$ DM) & 0.018 & 0.012 \\
\hline Fat $(\mathrm{g} / 100 \mathrm{~g}$ DM) & Not detected & 0.013 \\
\hline Fibre $(\mathrm{g} / 100 \mathrm{~g}$ DM) & 0.036 & 0.025 \\
\hline
\end{tabular}




\begin{tabular}{|l|c|c|}
\hline Total Carbohydrates (g/100g DM) & 0.965 & 0.878 \\
\hline $\mathrm{pH}$ & 6.49 & 6.34 \\
\hline Cyanide as HCN (mg/kg dry weight) & 2.55 & 1.76 \\
\hline
\end{tabular}

\section{Conclusions}

Drying of cassava chips (variety MMEX 59) was successfully carried out in a mechanical oven. Drying to a safe moisture content of $13 \%(\mathrm{wb})$ was achieved by drying larger chips $(3 \times 2 \times 1 \mathrm{~cm})$ for approximately $7 \mathrm{~h}$ and smaller chips $(0.8 \times 0.6 \times 0.4 \mathrm{~cm})$ for $3 \mathrm{~h}$. Chip size did not affect overall appearance and quality of the dried product, but the smaller chip size would be recommended for cassava export based solely on the rapid drying rate. Drying of the chips occurred in the falling rate period only. Moisture ratio data for the larger and smaller chips was successfully modelled using the Hii and Page models, respectively. These models, together with the experimental values of initial and equilibrium moisture content, were used to determine the extent of drying completed and the moisture content of chips during the drying process at any point in time $(\mathrm{t})$. While it appears to be established that drying of cassava chips occurs in the falling rate period only, the range of models used to describe the drying process highlights the variability with respect to the decline in moisture content with time. For process control, it is therefore important that the process be studied for the type of cassava, average piece sizes and specific drying conditions. This type of information could therefore allow a dryer operator to more closely monitor the drying process. Recommendations for future work includes the collection of drying data of MMEX 59 cassava chips dried at a range of drying temperatures, which can be used to build a database to predict sample moisture content at any time during the drying process.

Acronyms, Abbreviations and Symbols

$\begin{array}{ll}\mathrm{A} & \text { Drying constant } \\ \mathrm{D}_{\text {eff }} & \text { Diffusion coefficient }\left(\mathrm{m}^{2} / \mathrm{s}\right) \\ \mathrm{DM} & \text { Dry matter }(\mathrm{g}) \\ \mathrm{k} & \text { Drying rate constant }(1 / \mathrm{h}) \\ \mathrm{L} & \text { Half thickness of sample }(\mathrm{m}) \\ \mathrm{M} & \text { Moisture content }\left(\mathrm{g} \mathrm{H}_{2} \mathrm{O} / \mathrm{g} \mathrm{DM}\right) \text { at time }=\mathrm{t} \\ \mathrm{M}_{\mathrm{o}} & \text { Initial Moisture Content }\left(\mathrm{g} \mathrm{H}_{2} \mathrm{O} / \mathrm{g} \mathrm{DM}\right) \\ \mathrm{M}_{\mathrm{e}} & \text { Equilibrium Moisture Content }\left(\mathrm{g} \mathrm{H}_{2} \mathrm{O} / \mathrm{g} \mathrm{DM}\right) \\ \mathrm{MR} & \text { Moisture Ratio }\left(\mathrm{M}-\mathrm{M}_{\mathrm{e}}\right) /\left(\mathrm{M}_{\mathrm{o}}-\mathrm{M}_{\mathrm{e}}\right) \\ \mathrm{R}^{2} & \text { Coefficient of determination } \\ \mathrm{RMSE} & \text { Root Mean Square Error } \\ \mathrm{K}, \mathrm{a}, \mathrm{n}, \mathrm{c}, \mathrm{g} & \text { Model constants } \\ \mathrm{t} & \text { Time }(\mathrm{h}) \\ \mathrm{wb} & \text { Wet basis }\left(\mathrm{g} \mathrm{H}_{2} \mathrm{O} / 100 \mathrm{~g} \mathrm{FW}\right) \\ \chi^{2} & \text { Chi-Square }\end{array}$

\section{References}

[1] East African Community. 2010. Dried cassava chips - Specification East African Standard EAS 739:2010. https://law.resource.org/pub/eac/ibr/eas.739.2010.html. Date accessed: December 26, 2019.

[2] Department of Agriculture, Bureau of Agriculture and Fisheries Product Standards. 2010. Bureau of Product Standards/Philippine National Standard PNS/BAFPS29:2010 - Dried Cassava Chips and granules. Department of Agriculture, Bureau of Agriculture and Fisheries Product Standards.

[3] P. Titus, J. Lawrence, A. Seesahai. 2011. Commercial Cassava Production Technical Bulletin SK 
001/10. Caribbean Agricultural and Research and Development Institute (CARDI): Basseterre, St. Kitts and Nevis.

[4] P. Titus, J. Lawrence J. 2015. Cassava and sweet potato: suitability of popular Caribbean varieties for value added product development. Inter-American Institute for Cooperation on Agriculture (IICA). Port of Spain, Trinidad.

[5] J. H. Cock. 1985. Cassava, New Potential for a neglected crop. IADS Development Oriented Literature Series. West View Press, Boulder and London, UK. 1985.

[6] M.A. Salgado, A. Lebert, H.S. Garcia, J. Muchnik and J.J. Bimbenet. Development of the characteristic drying curve for cassava chips in monolayer. Drying Technology: An International Journal 12 no.3, (1994) 685-696.

[7] S.T.A.R. Kajuna, V.C.K. Silayo, A. Mkenda, P.J.J. Makungu. Thin-layer drying of diced cassava roots. African Journal of Science and Technology 2 no.2, (2001) 94-100.

[8] T.Y. Tunde-Akintunde, A.A. Afon. Modelling of hot-air drying of pretreated cassava chips. Agricultural Engineering International: CIGR Journal 12 no. 2, (2010) 34- 41.

[9] M.A. Usman, P.Y. Idakkwo. Size Reduction of cassava chips and the drying rate. Journal of Research in National Development 9 no.1, (2011) 79-87.

[10] A.S. Ajala, F.A. Ajala, J.O. Oyedele. Drying characteristics and mathematical modelling of cassava chips. American Journal of Engineering Research (AJER) 4 no. 5, (2012) 45-49.

[11] P. Pornpraipech, M. Khusakul, R. Singklin, P. Sarabhorn, C. Areeprasert. Effect of temperature and shape on drying performance of cassava chips. Agriculture and Natural Resources 51 no. 5, (2017) 402409.

[12] D.L.S. Tan, J.H. Perez, L.M. Diamante. Thin-layer drying of cassava chips and grates. Acta Horticulturae 703 (2006), 233-240.

[13] F.T. Ademiluyi, K. Oduola, J. Eke, J. Eke-Ejiofor. Mathematical modeling of drying different cassava chips in thin layers. Journal of the Nigerian Society of Chemical Engineers 22 (2007) 149-157.

[14] C. Chávez-Mendez, M.A. Salgado-Cervantes, K.N. Waliszewski-Kubiak, M.A. Garcia-Alvarado. Fitting cassava drying kinetic with a high order equation. Drying Technology: An International Journal 16 no.1-2, (1998) 323-331.

[15] AOAC (2000) Official Methods of Analysis. 17th Edition, The Association of Official Analytical Chemists, Gaithersburg, MD, USA.

[16] AOAC (2005) Official Methods of Analysis. 18th Edition, The Association of Official Analytical Chemists, Gaithersburg, MD, USA.

[17] Z. Erbay, F. Icier F. A review of thin layer drying of foods: theory, modeling, and experimental results. Critical Reviews in Food Science and Nutrition 50 no. 5, (2010) 441-64.

[18] C. Ertekin, M.Z. First. A comprehensive review of thin-layer drying models used in agricultural products. Critical Reviews in Food Science and Nutrition 57 no. 4, (2017) 701-717.

[19] Hyams, D. G. (2016), CurveExpert Professional Software, Version 2.3. http://www.curveexpert.net. Date accessed June 30th, 2019.

[20] S. Charmongkolpradita, R. Luamponb. Study of thin layer drying model for cassava pulp. Energy Procedia 138 (2017) 354-359.

[21] J. Kwok. 2008. Cyanide Poisoning and Cassava. Food Safety Focus (19th Issue, February 2008) Incident in Focus. Centre for Food Safety, The Government of Hong Kong Special Administrative Region. https://www.cfs.gov.hk/english/index.html. Date accessed: December 26, 2019

[22] J. Sulistyo, L.J. Shya, H. Mamat, N.A. Wahab. Nutritional value of fortified cassava flour prepared from modified cassava flour and fermented protein hydrolysates. AIP Conference Proceedings 1744, 020030 (2016).

[23] O. B. Ifeabunike, J. M. Nwaedozie, C. I. Aghanwa. Proximate analysis, hydrogen cyanide and some essential mineral content of sweet cassava variety (Manihot utilisima) and bitter cassava variety (Manihot palmata) cultivated in Kachia local government area of Kaduna State, Nigeria. International Journal of Biochemistry Research \& Review 19 no. 1, (2017) 1-12. 